\title{
Production and composition of oranges cv. Lane Late under maintenance potassium fertilization
}

\section{Produção e composição de frutos de laranjeira cv. Lane Late submetida à adubação potássica de manutenção}

\author{
Gustavo Brunetto ${ }^{1 *}$; Cesar Cella ${ }^{2}$; João Kaminski ${ }^{1}$; Auri Brackmann 3 ; \\ Alcione Miotto ${ }^{4}$; Carlos Alberto Ceretta ${ }^{1}$; Paulo Ademar Avelar Ferreira ${ }^{4}$; \\ Márcio Renan Weber Schorr ${ }^{5}$; Vanderlei Both ${ }^{5}$; Vítor Gabriel Ambrosini ${ }^{6}$
}

\begin{abstract}
This study aimed to assess the production and composition of oranges from cv. Lane Late trees submitted to maintenance potassium fertilization. The experiment was conducted in an orchard of cv. Lane Late at Rosário do Sul (RS). The orange trees were submitted to supplementation with 0, 50 or $100 \%$ of the recommended dose of $\mathrm{K}_{2} \mathrm{O}$ in each crop season from 2008/2009 to 2011/2012. Fruit production, fruit diameter, peel thickness, juice volume and juice, leaf and soil K levels were assessed in the 2008/2009, 2010/2011 and 2011/2012 crop seasons. Fruit composition parameters were assessed in the 2010/2011 and 2011/2012 crop seasons. The application of increasing doses of potassium to $\mathrm{cv}$. Lane Late orange trees for three crop seasons had no effect on fruit production. However, soil supplementation with potassium increased the total nutrient levels in the leaves and juice.
\end{abstract}

Key words: Leaf analysis. Citrus sinensis L. Fruit quality.

\section{Resumo}

O objetivo do trabalho foi avaliar a produção e a composição de frutos de laranjeiras cv. Lane Late submetidas à adubação potássica de manutenção. $\mathrm{O}$ experimento foi conduzido em um pomar da cv. Lane Late, em Rosário do Sul (RS). Nas safras 2008/2009 até 2011/2012 as laranjeiras foram submetidas à adição de 0,50 e $100 \%$ da dose de $\mathrm{K}_{2} \mathrm{O}$ recomendada. Nas safras 2008/2009, 2010/2011 e 2011/2012 foi avaliada a produção de frutos, o diâmetro de fruto, espessura da casca, volume de suco, os teores de K no suco, nas folhas e no solo. Nas safras de 2010/2011 e 2011/2012 foi avaliado o teor de vitamina C no suco, sólidos solúveis totais (SST), acidez total titulável (ATT), calculado o ratio e determinada a cor do suco e da epiderme dos frutos. A dose do fertilizante potássico, em três safras, não afeta a produção de frutos. A adição de $100 \%$ da dose aumenta o teor de K trocável no solo, o teor nas folhas e no suco, que apresenta cor mais amarelada.

Palavras-chave: Análise foliar. Citrus sinensis L. Qualidade do fruto.

${ }^{1}$ Profs. Drs., Dept ${ }^{\circ}$ de Solos e do Programa de Pós-Graduação em Ciência do Solo, PPGCS, Universidade Federal de Santa Maria, UFSM, Santa Maria, RS, Brasil. E-mail: brunetto.gustavo@gmail.com; joao.kaminski@gmail.com; carlosceretta@gmail.com

2 Eng $^{\circ}$ Agr $^{\circ}$, Dept $^{\circ}$ de Solos, UFSM, Santa Maria, RS, Brasil. E-mail: cesarcella.com@gmail.com

3 Prof. Dr., Dept ${ }^{\circ}$ de Fitotecnia, UFSM, Santa Maria, RS, Brasil. E-mail: auribrackmann@gmail.com

${ }^{4}$ Discentes de Pós-Doutorado, PPGCS, UFSM, Santa Maria, RS, Brasil. E-mail: avelarufla@gmail.com; alcionemiotto@gmail. com

${ }^{5}$ Mestres, Programa de Pós-Graduação em Agronomia, PGA, UFSM, Santa Maria, RS, Brasil. E-mail: marcioschorr@hotmail. com; vanderleiboth@yahoo.com.br

${ }^{6}$ M.e, PPGCS, Universidade Federal do Rio Grande do Sul, UFRGS, Porto Alegre, RS, Brasil. E-mail: vgambrosini@gmail.com

* Author for correspondence 


\section{Introduction}

Rio Grande do Sul (RS) has approximately 42 thousand hectares cultivated with citrus trees, which is the fifth largest area of the country (ALMEIDA et al., 2013). Since the 1970s, sandy soils of the Pampa (Campanha Gaúcha) have been incorporated into the citrus production system, especially with sweet orange (Citrus sinensis L.) cultivars, including $\mathrm{cv}$. Lane Late.

The soil in which the orchards are installed predominantly has sandy surface texture and low fertility, with nutrient levels naturally in middle and low availability ranges (CQFS-RS/SC, 2004). Thus, the application of lime and fertilizer in preplanting and maintenance fertilization throughout the production period becomes indispensable.

Recommended fertilization criteria for citrus in Rio Grande do Sul are reported in the fertilization and soil liming Handbook for the states of Rio Grande do Sul and Santa Catarina (CQFS-RS/SC, 2004). However, unlike states with a longer tradition of citrus cultivation, namely São Paulo, where in numerous studies on potassium fertilization have already been conducted (QUAGGIO et al., 2006, 2011), in RS, the dosage of potassium (K) to be used has not been established in regional calibration experiments. Therefore, the impact of the dose of $\mathrm{K}$ on total leaf levels of $\mathrm{K}$, fruit production and fruit production components such as vitamin $\mathrm{C}$, total soluble solids (TSS), total titratable acidity (TTA), TSS/TTA ratio, fruit skin color and juice color remains unknown.

Citrus supplementation with $\mathrm{K}$ may affect nutritional status, fruit production and fruit composition (QUAGGIO et al., 2006, 2011). However, low citrus response to supplementation with $\mathrm{K}$ may occur over the years. This results from the deposition in soil of non-exchangeable $\mathrm{K}$ forms, as observed in annual crops (KAMINSKI et al., 2007; ROSOLEM et al., 2012). Therefore, a strong chemical gradient towards the rhizosphere is created because the mechanisms controlling $\mathrm{K}$ absorption in higher plants are effective. Thus, the K supply is buffered by exchange sites contained in the interlayers of clay minerals and primary minerals to which exchangeable $\mathrm{K}$ forms adsorb with low binding energy and non-exchangeable $\mathrm{K}$ forms adsorb with high binding energy (KAMINSKI et al., 2007).

The growth of cover plant species that can absorb $\mathrm{K}$ from the deepest soil layers, cycling it via the decomposition of shoot residues deposited on the soil surface and decaying senescent roots, is observed in interrows (HEINZ et al., 2011; BRITO et al., 2014). Furthermore, the lack of plant response to fertilization may be related to internal $\mathrm{K}$ stores, especially in perennial organs formed in previous years, which may be redistributed to other organs during later cycles (ROCCUZZO et al., 2012).

This study aimed to assess the production and composition of oranges from cv. Lane Late trees submitted to maintenance potassium fertilization because studies on the response of orange trees to soil $\mathrm{K}$ fertilization, especially in soil with sandy surface texture and with a history of potassium fertilization, are scarce in southern Brazil.

\section{Materials and Methods}

The experiment was conducted in a commercial orchard of cv. Lane Late orange trees grafted onto Poncirus trifoliata rootstocks in Rosário do Sul (RS) (Campanha Gaúcha Central; 30¹5’26.75”S latitude; 5458'43.72”'W longitude; datum WGS84). The orchard was planted in 2004, with $6.0 \mathrm{~m}$ interrow spacing and $3.0 \mathrm{~m}$ interplant spacing, totaling 555 plants per hectare. The regional climate is humid subtropical, type Cfa 2. The temperature and rainfall results observed throughout the experiment are shown in Figure 1. The soil was classified as Sandy Typic Hapludalf soil and had the following composition in the 0-20 $\mathrm{cm}$ layer before the experiment: $80 \mathrm{~g} \mathrm{~kg}^{-1}$ clay; $15 \mathrm{~g} \mathrm{~kg}^{-1}$ organic matter; $\mathrm{pH} 5.7$ in water; $76 \mathrm{mg}$ $\mathrm{dm}^{-3}$ available $\mathrm{P}$ and $80 \mathrm{mg} \mathrm{dm}{ }^{-3}$ exchangeable $\mathrm{K}$ 
(both extracted using Mehlich 1) (TEDESCO et al., 1995); $70 \mathrm{mg} \mathrm{kg}^{-1}$ non- exchangeable $\mathrm{K}$ (extracted using $1 \mathrm{~mol} \mathrm{~L}^{-1} \mathrm{HNO}_{3}$ ) (PRATT, 1965); $4.4 \mathrm{cmol}_{\mathrm{c}}$ $\mathrm{dm}^{-3}$ exchangeable $\mathrm{Ca}, 0.8 \mathrm{cmol}_{\mathrm{c}} \mathrm{dm}^{-3}$ exchangeable
$\mathrm{Mg}$ (both extracted using $1 \mathrm{~mol} \mathrm{~L}^{-1} \mathrm{KCl}$ ) and 6.8 $\mathrm{cmol}_{\mathrm{c}} \mathrm{dm}^{-3}$ cation exchange capacity $(\mathrm{CEC})_{\mathrm{pH}} 7.0$ (TEDESCO et al., 1995).

Figure 1. Rainfall, maximum temperature (upper lines) and minimum temperature (lower lines), climatological norms and values recorded in the period from September 2008 to August 2012 in Rosário do Sul (RS).

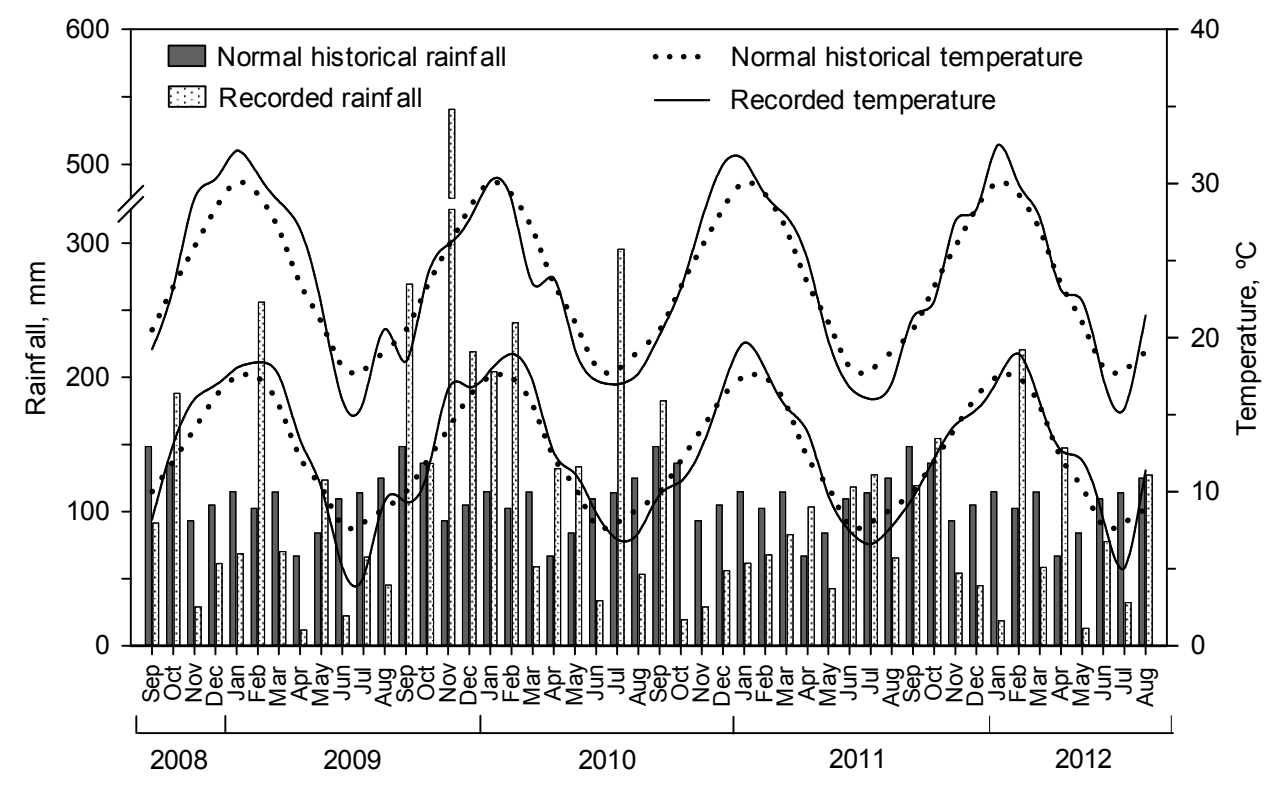

The experiment was installed in 2008 and conducted in the crop seasons from 2008/2009 to $2011 / 2012$ in a completely randomized block design, with eight replicates. Each plot consisted of seven plants, and the five central plants were evaluated. Three treatments were applied: 0, 50 and $100 \%$ of the recommended dose of $\mathrm{K}_{2} \mathrm{O}$, according to the Soil Chemistry and Fertility Commission of Rio Grande do Sul and Santa Catarina (CQFS-RS/ $\mathrm{SC}$; 2004). The dose of $\mathrm{K}_{2} \mathrm{O}$ corresponding to $100 \%$ was $36 \mathrm{~g} \mathrm{~K}_{2} \mathrm{O}$ plant $^{-1}$ year $^{-1}$, equivalent to $20 \mathrm{~kg} \mathrm{~K}_{2} \mathrm{O}$ $\mathrm{ha}^{-1}$ year $^{-1}$. The doses of $\mathrm{K}_{2} \mathrm{O}$ were applied as $\mathrm{KCl}$ $\left(58 \% \mathrm{~K}_{2} \mathrm{O}\right)$ and broadcast on the soil surface under the canopy and without incorporation (CQFS-RS/ $\mathrm{SC}, 2004)$. The application of $\mathrm{K}_{2} \mathrm{O}$ occurred in the month of September each year from 2008 to 2011.

Chemical weeding was performed in the interrows during the four experimental crop seasons. The interrow vegetation, mainly consisting of bahiagrass (Paspalum notatum), creeping beggarweed (Desmodium incanum) and arrowleaf clover (Trifolium vesiculosum), was controlled with mowing at approximately $15 \mathrm{~cm}$ height. Fertilization with nitrogen (as urea) and phosphate (as triple superphosphate (TSP)) were performed during the experiment according to the CQFS-RS/SC (2004).

In January 2009, 2011 and 2012, 15 to 20 leaves resulting from spring sprouting were collected per plant from fruit branches aged from 5 to 7 months approximately $1.5 \mathrm{~m}$ above the soil in each of the four quadrants of the canopy (CQFS-RS/SC, 2004). The leaves were dried in a convection oven at $65^{\circ} \mathrm{C}$ until reaching constant weight and were subsequently ground and submitted to analysis of total K levels (TEDESCO et al., 1995).

The fruits produced by each plant were measured 
and weighed in August 2009, 2011 and 2012 at the time of harvest. Subsequently, five fruits per plant were selected randomly and sent to the laboratory, wherein the mean diameter and peel thickness of each fruit were measured in the median area using a caliper. The same fruits were juiced and the volume produced was quantified, with total $\mathrm{K}$ levels also being assessed after digestion with sulfuric acid (TEDESCO et al., 1995).

The juice levels of vitamin C, TSS and TTA were quantified in the 2010/2011 and 2011/2012 crop seasons, subsequently assessing the (TSS/ TTA) ratio (INSTITUTO ADOLFO LUTZ, 2008). Furthermore, the color of both the orange skin and juice were assessed using a digital colorimeter (Minolta, model CR310) with $\mathrm{L}^{*} \mathrm{C}^{*} \mathrm{H}^{\circ}$ threedimensional color reading scale (CIELAB). The $\mathrm{L}$ value represents luminosity, ranging from black $(\mathrm{L}=0)$ to white $(\mathrm{L}=100)$. The chroma $(\mathrm{C})$ value represents color intensity and equals zero in the center of the three-dimensional layout and increases as it moves away from it. The hue $\left(\mathrm{H}^{\circ}\right)$ represents color tone, wherein the angle $0^{\circ}$ represents pure red, $90^{\circ}$ represents pure yellow, $180^{\circ}$ pure green and $270^{\circ}$ blue. Skin color assessment was performed on five fruits of each replicate, from the equatorial region and from the sparsest and densest orange quadrants.

Soil was also collected from the $0-20 \mathrm{~cm}$ layer and in the range in which potassium fertilizer application was performed during the fruit crop season dates. Subsequently, the soil was dried, ground, sieved through a $2 \mathrm{~mm}$ mesh and the exchangeable $\mathrm{K}$ levels were then assessed (TEDESCO et al., 1995). The level of non-exchangeable $\mathrm{K}$ was also assessed in soil samples collected in 2012, at the end of the experiment, using boiling nitric acid (PRATT, 1965).
The volume of rainfall was high throughout the flowering period in the 2009/2010 crop season, which impaired production; therefore it was decided to forgo the assessment of production or its components.

The data collected separately in each crop season were submitted to analysis of variance using the software Assistat (SILVA, 2015), and when significant, the means were compared using Tukey's test ( $\mathrm{p}>0.05)$.

\section{Results and Discussion}

The highest leaf $\mathrm{K}$ levels were observed upon supplementation with $\mathrm{K}_{2} \mathrm{O}$, regardless of the $\mathrm{K}_{2} \mathrm{O}$ dose applied or crop season tested. Conversely, supplementation with $\mathrm{K}_{2} \mathrm{O}$ only showed a significant effect on the leaf $\mathrm{K}$ levels in the 2008/2009 and 2010/2011 crop seasons, with no difference between 50 and $100 \%$ of the recommended dose (Table 1).

The leaf $\mathrm{K}$ levels of plants without supplementation with $\mathrm{K}_{2} \mathrm{O}$ and with supplementation with 50 or $100 \%$ of the $\mathrm{K}_{2} \mathrm{O}$ dose were assessed as close to the normal range (1.0-1.5\%) (CQFS$\mathrm{RS} / \mathrm{SC}, 2004)$. However, it should be emphasized that the leaf $\mathrm{K}$ levels of plants from all treatments in the 2011/2012 crop season were lower than the leaf $\mathrm{K}$ levels of plants from the previous crop seasons. That finding most likely resulted from the reduced rainfall assessed in January 2012, when the leaves were collected (Figure 1). This phenomenon may have decreased the availability of soil water, reducing the contact between $\mathrm{K}$ and the outer surface of roots by mass flow and, in particular, by diffusion, or even complicating its transport within plants to sink organs, including leaves (OLIVEIRA et al., 2004). 
Table 1. Production and composition of oranges and juice cv. Lane Late trees planted in soil without potassium fertilization or with $50 \%$ or $100 \%$ of the recommended dose of potassium fertilizer.

\begin{tabular}{|c|c|c|c|c|c|c|c|}
\hline Parameter & \multicolumn{2}{|c|}{ Control } & \multicolumn{2}{|c|}{$50 \%$} & \multicolumn{2}{|c|}{$100 \%$} & $\mathrm{CV}, \%$ \\
\hline Production, kg plant ${ }^{-1}$ & 32.1 & $\mathrm{a}$ & 34.4 & $\mathrm{a}$ & 25.9 & $\mathrm{a}$ & 23.4 \\
\hline Production, $\mathrm{Mg} \mathrm{ha}^{-1}$ & 17.8 & a & 19.1 & a & 14.4 & $\mathrm{a}$ & 23.4 \\
\hline Fruit diameter, $\mathrm{cm}$ & 8.2 & $\mathrm{a}$ & 7.9 & a & 7.8 & $\mathrm{a}$ & 2.5 \\
\hline Skin thickness, $\mathrm{cm}$ & 0.45 & $\mathrm{a}$ & 0.50 & $\mathrm{a}$ & 0.49 & $\mathrm{a}$ & 7.3 \\
\hline Juice, $\mathrm{ml}$ & 733.1 & $\mathrm{a}$ & 650.6 & $\mathrm{a}$ & 689.4 & $\mathrm{a}$ & 8.6 \\
\hline Total juice $\mathrm{K}, \%$ & 0.17 & $b^{*}$ & 0.19 & $\mathrm{a}$ & 0.18 & $\mathrm{a}$ & 4.5 \\
\hline Total leaf K, \% & 1.39 & $b^{*}$ & 1.50 & $\mathrm{a}$ & 1.45 & $\mathrm{a}$ & 4.5 \\
\hline Soil exchangeable $\mathrm{K}, \mathrm{mg} \mathrm{kg}^{-1}$ & 81.6 & $\mathrm{~b}^{* *}$ & 73.7 & $\mathrm{~b}$ & 112.0 & $\mathrm{a}$ & 20.3 \\
\hline Fruit $\mathrm{K}$ export, $\mathrm{kg} \mathrm{ha}^{-1}$ & 18.57 & $\mathrm{a}$ & 20.88 & a & 15.29 & $\mathrm{a}$ & 20.4 \\
\hline Production, $\mathrm{kg}_{\text {plant }}{ }^{-1}$ & 31.3 & $\mathrm{a}$ & 28.7 & $\mathrm{a}$ & 20.6 & $\mathrm{a}$ & 30.2 \\
\hline Production, $\mathrm{Mg} \mathrm{ha}^{-1}$ & 17.4 & $\mathrm{a}$ & 15.9 & $\mathrm{a}$ & 11.4 & $\mathrm{a}$ & 30.2 \\
\hline Fruit diameter, $\mathrm{cm}$ & 7.5 & a & 7.6 & a & 7.5 & $\mathrm{a}$ & 2.3 \\
\hline Skin thickness, cm & 0.28 & $\mathrm{a}$ & 0.37 & $\mathrm{a}$ & 0.33 & $\mathrm{a}$ & 12.8 \\
\hline Juice, ml & 536.3 & $\mathrm{a}$ & 525.0 & $\mathrm{a}$ & 530.0 & $\mathrm{a}$ & 10.0 \\
\hline Vitamin C, mg $100 \mathrm{ml}^{-1}$ & 55.0 & $\mathrm{a}$ & 54.0 & $\mathrm{a}$ & 55.0 & $\mathrm{a}$ & 6.7 \\
\hline Total soluble solids, ${ }^{\circ}$ Brix & 10.5 & $\mathrm{a}$ & 9.8 & $\mathrm{a}$ & 10.3 & $\mathrm{a}$ & 3.4 \\
\hline Total titratable acidity, g citric acid $100 \mathrm{ml}^{-1}$ & 1.12 & $\mathrm{a}$ & 1.07 & $\mathrm{a}$ & 1.15 & $\mathrm{a}$ & 10.6 \\
\hline Ratio & 9.4 & a & 9.4 & a & 9.0 & $\mathrm{a}$ & 10.0 \\
\hline Total juice $\mathrm{K}, \%$ & 0.21 & $b^{*}$ & 0.22 & $\mathrm{a}$ & 0.23 & $\mathrm{a}$ & 6.7 \\
\hline Total leaf K, \% & 1.58 & $b^{*}$ & 1.82 & a & 1.86 & $\mathrm{a}$ & 11.9 \\
\hline Soil exchangeable $\mathrm{K}, \mathrm{mg} \mathrm{kg}^{-1}$ & 77.6 & $b^{*}$ & 70.9 & $\mathrm{~b}$ & 91.4 & $\mathrm{a}$ & 17.0 \\
\hline Fruit $\mathrm{K}$ export, $\mathrm{kg} \mathrm{ha}^{-1}$ & 18.28 & a & 16.11 & a & 14.93 & $\mathrm{a}$ & 21.6 \\
\hline Production, kg plant ${ }^{-1}$ & 37.2 & $\mathrm{a}$ & 48.3 & $\mathrm{a}$ & 39.9 & $\mathrm{a}$ & 23.8 \\
\hline Production, $\mathrm{Mg} \mathrm{ha}^{-1}$ & 20.6 & $\mathrm{a}$ & 26.8 & $\mathrm{a}$ & 22.1 & $\mathrm{a}$ & 23.8 \\
\hline Fruit diameter, $\mathrm{cm}$ & 7.5 & $\mathrm{a}$ & 7.5 & $\mathrm{a}$ & 7.7 & $\mathrm{a}$ & 3.8 \\
\hline Skin thickness, cm & 0.45 & $\mathrm{a}$ & 0.48 & $\mathrm{a}$ & 0.45 & $\mathrm{a}$ & 7.7 \\
\hline Juice, $\mathrm{ml}$ & 528.8 & $\mathrm{a}$ & 525.6 & $\mathrm{a}$ & 585.0 & $\mathrm{a}$ & 11.9 \\
\hline Vitamin $C, \operatorname{mg~} 100 \mathrm{ml}^{-1}$ & 67.0 & $\mathrm{a}$ & 66.0 & $\mathrm{a}$ & 65.0 & $\mathrm{a}$ & 5.6 \\
\hline Total soluble solids, ${ }^{\circ} \mathrm{Brix}$ & 14.0 & $\mathrm{a}$ & 13.8 & $\mathrm{a}$ & 13.9 & $\mathrm{a}$ & 3.8 \\
\hline Total titratable acidity, g citric acid $100 \mathrm{ml}^{-1}$ & 0.89 & $\mathrm{a}$ & 0.97 & a & 0.90 & $\mathrm{a}$ & 7.7 \\
\hline Ratio & 15,7 & a & 14.3 & a & 15.4 & $\mathrm{a}$ & 6.2 \\
\hline Total juice $\mathrm{K}, \%$ & 0.20 & $b^{*}$ & 0.23 & $\mathrm{a}$ & 0.23 & $\mathrm{a}$ & 4.0 \\
\hline Total leaf K, \% & 1.00 & $\mathrm{a}$ & 1.06 & a & 0.92 & $\mathrm{a}$ & 7.3 \\
\hline Soil exchangeable $\mathrm{K}, \mathrm{mg} \mathrm{kg}^{-1}$ & 89.5 & $b^{* *}$ & 90.1 & $\mathrm{~b}$ & 130.8 & $\mathrm{a}$ & 18.4 \\
\hline Non-exchangeable $\mathrm{K}, \mathrm{mg} \mathrm{kg}^{-1}$ & 59.0 & $\mathrm{a}$ & 42.0 & a & 57.0 & $\mathrm{a}$ & 20.02 \\
\hline Fruit $\mathrm{K}$ export, $\mathrm{kg} \mathrm{ha}^{-1}$ & 24.23 & $\mathrm{~b}$ & 35.31 & $\mathrm{a}$ & 29.74 & $\mathrm{a}$ & 19.0 \\
\hline
\end{tabular}

(1) Means followed by the same lowercase letter in rows are not different from each other according to Tukey's test. ${ }^{* *}$ Significant at $\mathrm{p}>0.01 ;{ }^{*}$ Significant at $\mathrm{p}>0.05$. 
Neither the annual production of fruit nor fruit parameters such as diameter, vitamin C level, TSS, TTA and TSS/TTA ratio showed any significant difference between the doses of $\mathrm{K}_{2} \mathrm{O}$ applied in any crop season (Table 1) despite the increased K levels within plants upon supplementation with 50 and $100 \% \mathrm{~K}_{2} \mathrm{O}$ diagnosed according to the juice and leaf $\mathrm{K}$ levels (the latter assessed in two crop seasons).

The lack of response to application of $\mathrm{K}_{2} \mathrm{O}$ from fruit production or fruit composition parameters may have partly occurred because the soil's exchangeable $\mathrm{K}$ levels before implementing the experiment, derived from the source material and pre-planting potassium fertilization, was interpreted as high (61-120 $\mathrm{mg} \mathrm{dm}^{-3} \mathrm{~K}$, in a soil with 5.1-15.0 $\mathrm{cmol}_{\mathrm{c}} \mathrm{dm}^{-3} \mathrm{CEC}_{\mathrm{pH} 7.0}$ ), requiring $20 \mathrm{~kg} \mathrm{ha}^{-1}$ year $^{-1} \mathrm{~K}_{2} \mathrm{O}$ $\left(100 \%\right.$ of the dose of $\left.\mathrm{K}_{2} \mathrm{O}\right)$.

It should be noted that the exchangeable $\mathrm{K}$ levels of soil without $\mathrm{K}_{2} \mathrm{O}$ supplementation fluctuated very little over the three crop seasons assessed, although $20 \mathrm{~kg} \mathrm{ha}^{-1}$ year $^{-1} \mathrm{~K}$ was exported (mean of the three treatments), which may also partly explain the lack of response to soil supplementation with 50 and $100 \%$ of the dose of $\mathrm{K}_{2} \mathrm{O}$ from production, its parameters or fruit composition. This finding may also be partly attributable to the contribution of nonexchangeable $\mathrm{K}$ forms in soil (BRUNETTO et al., 2005; KAMINSKI et al., 2007; ROSOLEM et al., 2012) because the mechanisms controlling plant $\mathrm{K}$ absorption are efficient, which results in a strong chemical gradient towards the rhizosphere, creating a favorable environment for the release of nonexchangeable $\mathrm{K}$ forms (KAMINSKI et al., 2007).

$\mathrm{K}$ supply to plants is buffered by exchangeable $\mathrm{K}$ forms, adsorbed with low binding energy to the surface functional groups of soil reactive particles, and by non-exchangeable $\mathrm{K}$ forms. That was reflected in the 2011/2012 crop season, which showed decreases of 11,29 and $18 \%$ of non-exchangeable $\mathrm{K}$ (Table 1) in soil without $\mathrm{K}_{2} \mathrm{O}$ supplementation and with 50 and $100 \%$ of the dose of $\mathrm{K}_{2} \mathrm{O}$, respectively, compared to the $70 \mathrm{mg} \mathrm{kg}^{-1}$ initial mean level of non-exchangeable K. It should also be noted that a decrease in non-exchangeable soil $\mathrm{K}$ forms may even cause changes in phases of micaceous minerals containing $\mathrm{K}$, as observed by Bortoluzzi et al. (2005), similar to the soil of the present study.

The lack of response to potassium fertilization from the orange trees may also be attributed to the extensive root system of woody plants, which increases the volume of soil exploited in search for the water and nutrients such plants accumulate in their storage organs (ROCCUZZO et al., 2012). In the case of fruit trees, $\mathrm{K}$ export begins in the third or fourth year, when production becomes commercially viable, which retains the nutrient stores and yields are maintained even without the recommended corrective fertilization.

Furthermore, the roots of cover plants in the orchard interrows may have absorbed $\mathrm{K}$ from the deepest soil layers in all treatments, accumulating $\mathrm{K}$ in roots and shoot organs, which decompose when senescent, releasing $\mathrm{K}$ into regions close to the plant roots (HEINZ et al., 2011; BRITO et al., 2014). Furthermore, senescent leaves and branches deposited on the soil surface may have released $\mathrm{K}$ into the soil during their decomposition (TAGLIAVINI et al., 2007). Thus, $\mathrm{K}$ derived from the cycling of residues from cover plants in interrows and from senescent leaves and branches also may have contributed to the nutrition of the citrus plants from soil without $\mathrm{K}_{2} \mathrm{O}$ application, reducing the likelihood of plant response to the dose of $\mathrm{K}_{2} \mathrm{O}$. However, the lack of response of the plants may also be related to their internal $\mathrm{K}$ stores, especially in perennial organs formed in previous years, which may be redistributed to other organs during later cycles (ROCCUZZO et al., 2012).

Potassium fertilization in the 2010/2011 and 2011/2012 crop seasons had no effect on skin color as measured by luminosity (L), intensity (C) and tone $\left(\mathrm{H}^{\circ}\right)$ parameters (Table 2$)$, as observed for the other production parameters and fruit composition. 
Table 2. Juice and skin color of oranges cv. Lane Late trees planted in soil without potassium fertilization or with $50 \%$ or $100 \%$ of the recommended dose of potassium fertilizer.

\begin{tabular}{|c|c|c|c|c|c|c|c|c|c|c|c|c|}
\hline \multirow{3}{*}{$\begin{array}{c}\text { Potassium } \\
\text { maintenance doses }\end{array}$} & \multicolumn{12}{|c|}{ Color parameters } \\
\hline & \multicolumn{6}{|c|}{ Skin } & \multicolumn{6}{|c|}{ Juice } \\
\hline & \multicolumn{2}{|c|}{$\mathrm{L}$} & \multicolumn{2}{|c|}{$\mathrm{C}$} & \multicolumn{2}{|c|}{$\mathrm{H}^{\circ}$} & \multicolumn{2}{|c|}{$\mathrm{L}$} & \multicolumn{2}{|c|}{$\mathrm{C}$} & \multicolumn{2}{|c|}{$\mathrm{H}^{\circ}$} \\
\hline Control & 71.7 & $\mathrm{a}^{(1)}$ & 76.3 & $\mathrm{a}$ & 71.9 & $\mathrm{a}$ & 69.5 & $\mathrm{a}$ & 57.9 & $\mathrm{~b}^{* *}$ & 82.5 & $\mathrm{~b}^{* *}$ \\
\hline $50 \%$ & 71.4 & $\mathrm{a}$ & 73.2 & $\mathrm{a}$ & 75.0 & $\mathrm{a}$ & 69.8 & $\mathrm{a}$ & 60.9 & $\mathrm{a}$ & 85.5 & $\mathrm{a}$ \\
\hline $100 \%$ & 71.8 & $\mathrm{a}$ & 75.5 & $\mathrm{a}$ & 73.2 & $\mathrm{a}$ & 69.7 & $\mathrm{a}$ & 62.0 & $\mathrm{a}$ & 87.3 & $\mathrm{a}$ \\
\hline $\mathrm{CV}(\%)$ & 1.55 & & 2.16 & & 2.08 & & 2.36 & & 3.80 & & 1.88 & \\
\hline Control & 66.8 & $\mathrm{a}$ & 73.8 & $\mathrm{a}$ & 68.4 & $\mathrm{a}$ & 70.6 & $\mathrm{a}$ & 63.1 & $\mathrm{a}$ & 83.2 & $b^{*}$ \\
\hline $50 \%$ & 67.4 & $\mathrm{a}$ & 72.8 & $\mathrm{a}$ & 69.2 & $\mathrm{a}$ & 69.5 & $\mathrm{a}$ & 61.8 & $\mathrm{a}$ & 84.4 & $a b$ \\
\hline $100 \%$ & 66.2 & $\mathrm{a}$ & 72.0 & $\mathrm{a}$ & 67.8 & $\mathrm{a}$ & 69.4 & $\mathrm{a}$ & 63.7 & $\mathrm{a}$ & 86.2 & a \\
\hline CV (\%) & 1.80 & & 2.31 & & 2.80 & & 3.54 & & 3.85 & & 2.40 & \\
\hline
\end{tabular}

(1) Means followed by the same lowercase letter in rows are not different from each other according to Tukey's test. ${ }^{* *}$ Significant at $\mathrm{p}>0.01 ;{ }^{*}$ Significant at $\mathrm{p}>0.05$.

No response to potassium fertilization was observed for L, which represents juice darkening, regarding the orange juice's color. However, fruits from plants subjected to supplementation with 50 or $100 \%$ of the dose of $\mathrm{K}_{2} \mathrm{O}$ showed higher values of $\mathrm{C}$, which represents color intensity, especially in the 2010/2011 crop season. This gives them a more vivid and intense color and corroborates the total juice $\mathrm{K}$ levels (Table 1). The highest juice color $\mathrm{H}^{\mathrm{o}}$ of the 2010/2011 crop season was assessed upon supplementation with 50 and $100 \%$ of the dose of $\mathrm{K}_{2} \mathrm{O}$ (Table 2). The highest $\mathrm{H}^{\mathrm{o}}$ of the 2011/2012 crop season was recorded in the juice from oranges of plants subjected to supplementation with $100 \%$ of the dose of $\mathrm{K}_{2} \mathrm{O}$, although the juice was not significantly different from the juice produced upon supplementation with the $50 \% \mathrm{~K}_{2} \mathrm{O}$ dose. These findings indicate that the juice color from oranges of plants supplemented with 50 or $100 \%$ of the recommended dose of $\mathrm{K}_{2} \mathrm{O}$ - which showed higher total juice $\mathrm{K}$ levels (Table 1) - was closer to yellow, and the juice from oranges of plants without potassium fertilizer supplementation, with lower total $\mathrm{K}$ levels, had a more yellow-reddish color (Table 2).
Juice color is related to the type of carotenoids present in the sample. Although Meléndez-Martínez et al. (2010) concluded in their study that the carotenoids best correlated with the angle $\mathrm{H}^{\circ}$ of a juice sample are not necessarily those related to Chroma, the present study demonstrated a change in both parameters upon supplementation with potassium fertilizer, indicating that juice color is a parameter sensitive to soil supplementation with $\mathrm{K}$ and its increase in juice.

\section{Conclusions}

The application of increasing potassium doses to cv. Lane Late orange trees for three crop seasons had no effect on fruit production. However, soil supplementation with potassium increased the total leaf and juice levels of the nutrient.

\section{References}

ALMEIDA, S. C.; DÖRR, A. C.; ZULIAN, A.; SIDALI, K. L. Análise econômica da citricultura de rosário o Sul/RS: um enfoque sobre a adoção de programas de certificação socioambiental. Revista Eletrônica em Gestão, Educação e Tecnologia Ambiental, Santa Maria, v. 11, n. 11, p. 2427-2436, 2013. 
BORTOLUZZI, E. C.; RHEINHEIMER, D. S.; KAMINSKI, J.; GATIBONI, L. C.; TESSIER, D. Alterações na mineralogia de um Argissolo do Rio Grande do Sul submetido à fertilização potássica. Revista Brasileira de Ciência do Solo, Viçosa, MG, v. 29, n. 3, p. 327-335, 2005.

BRITO, O. R.; TELLES, T. S.; SCHNITZER, J. A.; GASPAR, G. G.; GUIMARÃES, M. F. The influence of crop residues in vertical soil mobility of potassium. Semina: Ciências Agrárias, Londrina, v. 35, n. 6, p. 3043-3052, 2014.

BRUNETTO, G.; GATIBONI, L. C.; RHEINHEIMER, D. S.; SAGGIN, A.; KAMNSKI, J. Nível crítico e resposta das culturas ao potássio em um Argissolo sob sistema plantio direto. Revista Brasileira de Ciência do Solo, Viçosa, MG, v. 29, n. 4, p. 565-571, 2005.

COMISSÃO DE QUÍMICA E FERTILIDADE DO SOLO - CQFS-RS/SC. Manual de adubação e calagem para os Estados do Rio Grande do Sul e de Santa Catarina. 10. ed. Porto Alegre: SBCS - Núcleo Regional Sul/UFRGS, 2004. 400 p.

HEINZ, R.; GARBIATE, M. V.; VIEGAS NETO, A. L.; MOTA, L. H. S.; CORREIA, A. M. P.; VITORINO, A. C. T. Decomposição e liberação de nutrientes de resíduos culturais de crambe e nabo forrageiro. Ciência Rural, Santa Maria, v. 41, n. 9, p. 1549-1555, 2011.

INSTITUTO ADOLFO LUTZ - IAL. Métodos físicoquímicos para análise de alimentos. São Paulo: Instituto Adolfo Lutz, 2008. 1020 p.

KAMINSKI, J.; BRUNETTO, G.; MOTERLE, D. F.; RHEINHEIMER, D. S. Depleção de formas de potássio do solo afetada por cultivos sucessivos. Revista Brasileira de Ciência do Solo, Viçosa, MG, v. 31, n. 5, p. 1003-1010, 2007.

MELÉNDEZ-MARTÍNEZ, A. J.; ESCUDEROGILETE, M. L.; VICARIO, I. M.; HEREDIA, F. J. Study of the influence of carotenoid structure and individual carotenoids in the qualitative and quantitative attributes of orange juice colour. Food Research International, Barking, v. 43, n. 5, p. 1289-1296, 2010.

OLIVEIRA, R. H.; ROSOLEM, C. A.; TRIGUEIRO, R. M. Importância do fluxo de massa e difusão no suprimento de potássio ao algodoeiro como variável de água e potássio no solo. Revista Brasileira de Ciência do Solo, Viçosa, MG, v. 28, n. 3, p. 439-445, 2004.
PRATT, P. F. Potassium. In: BLACK, C. A. (Ed.). Methods of soil analysis. Madison: Soil Science Society of America, 1965. p. 1022-1030.

QUAGGIO, J. A.; MATTOS JUNIOR, D.; BOARETTO, R. M. Sources and rates of potassium for sweet orange production. Scientia Agricola, Piracicaba, v. 68, n. 3, p. 369-375, 2011.

QUAGGIO, J. A.; MATTOS JUNIOR, D.; CANTARELLA, H. Fruit yield and quality of sweet oranges affected by nitrogen, phosphorus and potassium fertilization in tropical soils. Fruits, Les Ulis, v. 61, n. 5, p. 293-302, 2006.

ROCCUZZO, G.; ZANOTELLI, D.; ALLEGRA, M.; GIUFFRIDA, A.; TORRISI, B. F.; LEONARDI, A.; QUIÑONES, A.; INTRIGLIOLO, F.; TAGLIAVINI, M. Assessing nutrient uptake by field-grown orange trees. European Journal of Agronomy, Montpellier, v. 41, n. 1, p. 73-80, 2012.

ROSOLEM, C. A.; VICENTINI, J. P. T. M. M.; STEINER, F. Suprimento de potássio em função da adubação potássica residual em um Latossolo Vermelho do Cerrado. Revista Brasileira de Ciência do Solo, Viçosa, MG, v. 36, n. 5, p. 1507-1515, 2012.

SILVA, F. A. S. Sistema de assistência estatística Assistat versão 7.7 beta. Campina Grande: Universidade Federal de Campina Grande, 2015. Disponível em: $<$ http://www.assistat.com>. Accesso em: 23 jan. 2015.

TAGLIAVINI, M.; TONON, G.; SCANDELLARI, F.; QUIÑONES, A.; PALMIERI, S.; MENARBIN, G.; GIOACCHINI, P.; MASIA, A. Nutrient recycling during the decomposition of apple leaves (Malus domestica) and mowed grasses in an orchard. Agriculture, Ecosystems and Environment, Amsterdam, v. 118, n. 1, p. 191-200, 2007.

TEDESCO, M. J.; GIANELLO, C.; BISSANI, C. A.; BOHEN, H.; VOLKWEISS, S. J. Análises de solo, plantas e outros materiais. Porto Alegre: UFRGS/ Departamento de Solos, 1995. 174 p. (Boletim técnico, $5)$. 